\title{
ワーキングメモリにおけるフォーカス効果 ${ }^{1}$
}

\section{大阪外国語大学 苧阪満里子・西崎友規子・小森三恵 - 京都大学 苧阪直行}

\section{Effects of focus on working memory}

Mariko Osaka, Yukiko Nishizaki, Mie Komori (Psychological Laboratory, Department of Foreign Studies, Osaka University of Foreign Studies, Aomatani-higashi, Minoo 562-8558) and Naoyuki Osaka (Graduate School of Letters, Kyoto University, Yoshida-honmachi, Sakyo-ku, Kyoto 606-8501)

Effects of focus on a target word during performance of the reading span test (RST) were investigated. A focus word in the sentence was defined as the most critical word with a core meaning to integrate the sentence. Two kinds of RST were compared. One was focus-RST (F-RST) in which the target word to be maintained was a focus word of the sentence. The other was a non-focus-RST (NF-RST) in which the target word was not a focus word of the sentence, although the sentence did contain a focus word. Results showed that RST scores were found to be higher for F-RST than for NF-RST. Moreover, the effect of focus was proved to be dominant for low span subjects. Intrusion errors also increased in NF-RST. Sentence length effect, however, was not found. The results showed that low span subjects had severe deficits in making and updating the focus, which is critical for sentence comprehension.

Key words: working memory, focus, reading span test, sentence comprehension.

ワーキングメモリは，一時的な情報の保持と処理を 支える機構であり, 言語理解や学習, 思考といつたさ まざまな認知活動に重要な役割を果たしている (Baddeley, 1986; Just \& Carpenter, 1992). 高次の認知 活動に打いては，一次的に処理した内容を活性化状態 のまま並列的に保持しつつ，つぎに情報処理に対処す るということがたえず要求されている。ワーキングメ モリは，このような認知活動の遂行を統制する機能を 果たし，前頭葉をはじめとする高次脳機能を基盤とし てはたらいている。

ワーキングメモリのはたらきを考えるうえで重要な 点は, このような保持と処理のそれぞれの機能を支え るワーキングメモリには，処理資源に限界があるとい うことである。そこでは両者が処理資源を共有する資 源共有モデル（resource sharing model）が想定されて いる.

保持と処理とは必ずしも容量を競合するだけではな く，相互に促進する場合もある．たとえば読みの過程 では, 保持と処理はワーキングメモリの資源をめぐっ て競合するとともに，促進しあうこともある。という のは，文を読むときにはことばの意味を追いながら， 少しの時間ではあるが，すでに読んだ内容を心のなか

1 本研究は日本学術振興会科研費\#11610079（代表苧阪満里 子）と\#12301005（代表 苧阪直行）の助成を受けた。
に保持しておく必要があるためである。この保持され た内容は, 文脈となって続く処理を促進し, 文の統合 すなわち文理解に役立っている。その意味では，ワー キングメモリは，一時的な情報の保持機構であり，同 時に保持した内容を統合する過程を含むダイナミック な理解に向けてのシステムであるといえる(苧阪, 2000). 本研究では, 読みの処理にかかわるワーキン グメモリのはたらきを，フォーカスという新しい概念 を導入して検討した。

ワーキングメモリの処理資源は, 認知課題の要求す る情報の処理と保持の量が多ければ多いほど, 限界に 近づくこととなる。ワーキングメモリ資源が限界に近 づくと, 認知課題の遂行に制約が生じると考えられ る。たとえば，情報処理の効率が低下したり，誤りが 増加するといったように認知活動にさまざまな障害が でてくる。一方では, 保持が困難になり, 記憶してお かなければならないことを忘れてしまったり, 記憶し ていた内容が微妙に変容することもある。そこで, 限 界ある資源を，情報の処理にあてるか保持にあてるか をめぐって処理資源のトレードオフ（trade off）の関 係が生まれてくる。

また，資源限界のもとではワーキングメモリ容量の 個人差が顕著に現れると考えられる (Just \& Carpenter, 1992). リーディングスパンテスト（reading span test: 以下RST）はそのような状況のもとでワーキングメ 
モリの個人差を測定するテストである（Daneman \& Carpenter, 1980). RST では読みの過程における処理 と保持のトレードオフの関係が想定されていて, これ を用いて測定されたワーキングメモリ容量の個人差 が, 認知課題の遂行にどのような差をもたらすかが問 題とされてきた。その研究結果から, ワーキングメモ リ容量の個人差が高次な認知活動, とくに言語の処理 や理解の過程にさまざまな影響を及济していることが 検証されてきた (Just \& Carpenter, 1992).

RST は Daneman \& Carpenter (1980) の開発以後 多くの研究者により用いられてきた。というのは従来 の短期記憶研究で測定されてきた記憶範囲 (memory span）は，文章理解という高次の認知活動と相関が低 < (Daneman \& Carpenter, 1980; Perfetti \& Goldman, 1976), 言語理解における重要な側面を取り出すこと ができなかったのに対して, RST は文理解と高い相 関を示し, 認知活動の個人差を検討する有効な指標と して支持されてきたためである(Daneman \& Carpenter, 1980; Baddeley, Logie, Nimmo-Smith, \& Brereton, 1985; Masson \& Miller, 1983; 苧阪・苧阪, 1994)。RSTの日本語版を作成した苧阪・苧阪 （1994）でも英語版と同様に RST と読みの理解との相 関を認める結果を得ている.

一方, RSTの測定内容については, 研究者により いくつかの考方方が提案されている. Daneman \& Carpenter（1980；1983）は，文理解に必要な意味の 理解にかかわる処理が容量の差を引き出していると考 えている.さらに，このテストの高得点の被験者は多 くの方略を試すことができるなど, 問題解決能力にも すぐれていることを指摘している (Carpenter \& Just, 1989). 他方, RST 得点に保持した単語の語長効果が 認められるという結果から, RST は記憶範囲を測定 していると考える立場もある (La Pointe \& Engle, 1990)。上述のようにRST では資源共有を想定してい るのに対して, Towse, Hitch, \& Hutton (1998; 2000) は処理と保持を並列的におこなうことは難しいと考 え, 被験者はどちらかの作業を終了させた後で他の作 業を開始しているのではないかという仮説を提案し た。彼らは，処理と保持がワーキングメモリ資源を同 時に競合するのではなく, それぞれの作業ごとに注意 を転換してRST 課題を処理しているものと想定して いる (課題転換モデル, task switching model). さら に，抑制機能でRSTを説明しょうとする立場もある。 そこでは, RSTで低得点にとどまる被験者は, 課題 遂行に関連しない情報をうまく抑制できないと考えら れている（抑制機構モデル：inhibitory mechanism model; Conway \& Engle, 1994; Engle, Conway, Tuholski, \& Shisler, 1995; De Beni, Palladino, Pazzaglia, \& Cornoldi, 1998; May, Hasher, \& Kane, 1999).
以上のように，RST の測定内容の解釈をめぐって はいくつかの異なる解釈がある。しかし，いずれの立 場でも文理解の中核となるフォーカス (focus) の問 題には言及されていない, 文の読みにおいては, 読み 手は逐次的に目で追っている単語の意味をたえず活性 化するとともに，その語が文の理解に重要かどうかの 判断を扔こなっていると考元られる。ひとたび特定の 単語が文理解に重要な情報であると判断すると，すか さずそれを中心として心的な表象を構成していく，と いうのは，すべての情報を並列的に活性化させるより も，理解の中心軸となるフォーカスをつくりそれに必 要な情報のみを選択的に吸収していくほうが，はるか に負荷が少なく効率的であると考えられるためであ る。また，形成されたフォーカスは，その後の読みの 情報処理を促進するものと考元られる.同様の処理 は，RST 遂行時のプロセスにもそのままあてはまる。 被験者は，文を読みながら，文理解のフォーカスをた えず探索しているものと考えられる。

ワーキングメモリの個人差を測定するテストは RST 以外にも，カウンティングスパンテスト (counting span test; Case, Kurland, \& Goldberg, 1982)，オぺ レーションスパンテスト (operation span test; Turner \& Engle, 1989), 空間スパンテスト (spatial span test; Shah \& Miyake, 1996) などいくつか開発されている (近藤・森下・苧阪, 1999)。そのなかでも, RSTに 特徴的なのは, 文を読みつつ文末（日本語の場合は文 中）単語を保持するというように, 処理した内容を保 持する点である。これは, 保持すべき内容が処理した 内容と関連性があることに特徴づけられるといってよ い. それに対して, 他のスパンテストでは, 処理の内 容が保持した内容と比較的独立している。たとえば, オペレーションスパンテストのように, 足し算の正誤 判断をおこないながら, 問題の右端に書かれた足し算 とは関係のない数字や単語を保持するという作業であ る.ここでも, RST と同様に処理と保持のトレード オフが想定されている。しかしながら, RSTでの文 末単語は, あくまで文を構成する一つの要素であって 単なる 1 単語ではない. しかも, 英文の文末単語は多 くの場合, 文のフォーカスを担いうる重要な役割をも つ単語なのである(エンドフォーカス, end focus; Bolinger, 1986).

さて，英語 RST では記憶すべきターゲット語は文 末の単語であるが，日本語 RST（苧阪・苧阪， 1994）では構文構造を考慮して, 文中の下線が引かれ た単語をターゲット語として用いている。これは, 日 本語では文末には動詞がくる場合が多いため, 夕ーゲ ット語が動詞にかたよることを避けるためであった。 さらに, 英文では上述のエンドフォーカスの文構造が 多いのに対して, 日本語はほとんどエンドフォーカス とならない（久野，1978）こともその理由の一つであ 
る.

本研究では，このような文のフォーカスをもたらす 情報に注目して，フォーカスが単語の保持にどのよう に影響するのかを検討した。あわせて, RST の評価 内容について考察すると同時に，穴の異なる解釈例に ついても検討を加えた。

\section{目的}

本実験では，文のフォーカスとなる単語を同定し て，それがRST成績におよぼす影響を検討した。そ のため，あらかじめ評定された文のフォーカス語を夕 ーゲット語としたRST (focus-RST, F-RST) と，フ オーカス語以外の単語をターグット語としたRST (non-focus RST, NF-RST) を作成し，フォーカスと RST 成績との関連を検討した。ここでの仮説は，夕 ーゲット語がフォーカス語である場合には, 文のフォ 一カスが単語の保持に促進するため，F-RST と NFRST とに成績の差があらわれるということである.

また, 文の長さを変化させてフォーカスとのかかわ りを検討した。これは, 課題転換モデルの解釈につい て検討するためであった。このモデルの仮説に従うな らば，文の長さが長くなると，それだけターゲットの 保持時間が延長するため成績が低下すると予測され る.さらに, 読みと保持を課題転換しているならば, ターゲット語がフォーカス語であるか否かは, 単語再 生にはさほど影響を扔よぼさないであろうから，FRST と NF-RSTでは成績は変化しないと予想され る.

加えて, 本実験では RST の得点のみでなく, 単語 再生時に被験者が報告したエラーの数も分析の対象と した。これは，エラーの特性情報がワーキングメモリ の制御機能をさぐる糸口になるものと考えたためであ り，加えて抑制モデルの解釈と比較するためでもあっ た.

さらに, 被験者を日本語 RST(苧阪・苧阪, 1994）の高得点者と低得点者加選択して, 以上の効 果とワーキングメモリ容量の個人差との関連について 検討した。

\section{方 法}

\section{刺激文におけるフォーカス語の評定}

評定者 大阪外国語大学大学生 100 名.

刺激文 短文 (short sentence, S) は 25-30 文字か らなる 160 文を, 長文 (long sentence, L) は 35-40 文字からなる 160 文をいずれも中学校, 高等学校の国 語教科書などから抜粋した。1 文には必ず名詞が 2 単 語以上含まれていた。両単語とも，文頭抒よび文末以 外の文中位置に出現した。このため, 文はもとの文か
Table 1

Sample sentences of F-RST and NF-RST

F-RST

テレビ番組でわかめがいろいろな栄養素を含んでいること を知った。

$$
\text { フォーカス語：わかめ ターグット語：わかめ }
$$

\section{NF-RST}

テレビ番組でわかめがいろいろな栄養素を含んでいること を知った。

$$
\text { フォーカス語：わかめ ターゲット語：栄養素 }
$$

評定 被験者には, 文のなかで最も重要と考えられ る, 理解の中心となる単語（フォーカス語）を1語だ け選択させた。評定結果から，フォーカス語としての 同定が 70 パーセント以上得られた単語を含む文を短 文，長文それぞれ 84 文ずつ選択した。

\section{フォーカス-RST（F-RST）と非フォーカス-RST （NF-RST）の作成}

F-RST フォーカス語を含み，それを被験者が記 憶する単語（ターゲット語）としたRST。

NF-RST フォーカスとして選択した語は含まれて はいるが，それ以外の名詞単語をターゲット語とした RST.

ターゲット語は，2-4文字の名詞単語であり，漢 字, 仮名が半数になるよう設定された。さらに, ター ゲット語は通常その文字で表記されることが多いもの を用いた. Table 1 に, F-RST と NF-RST の例を示 す（文は実際には1行に書かれた）。

長短の F-RST と NF-RST 上記の F-RST と NFRSTから, 短文 F-RST (SF-RST), 短文 NF-RST (SNF-RST), 長文F-RST (LF-RST) および長文 NF-RST（LNF-RST）の 4 種類が作成された。短文 と長文の文の長さ (モーラ数) は, 短文が平均 33.67 $(S D=2.32)$ モーラ, 長文が平均 $44.62(S D=3.51)$ モーラであった。各試行内の短文は，できるだけ相互 に意味的関連性をもたない上う配慮された。また，夕 ーゲット語も試行内では意味的に関連しないようにし た。ターゲット語の文内での出現位置は文章ごとにラ ンダムとした。

被験者 大阪外国語大学大学生 40 名（男性 16 名, 女性 24 名)。そのうち，日本語版 RST（苧阪・苧阪， 1994）のスパン得点が 4.0 以上の被験者（High-span subjects, HSS, $M=4.45, S D=0.43)$ が 20 名, スパン 得点が 2.0 以下の被験者 (Low-span-subjects, LSS, $M=2.0, S D=0.0)$ が 20 名であった.

実験計画 被験者群 $(\mathrm{HSS} \cdot \mathrm{LSS}) \times$ フォーカス $(\mathrm{F} ・$ $\mathrm{NF}) \times$ 文の長さ $(\mathrm{L} \cdot \mathrm{S})$ の 3 要因計画とした。被験者 要因のみ被験者間要因であり, フォーカスと文の長さ 
は被験者内要因であった。

\section{RST の測定方法}

RST の実施方法は Osaka \& Osaka (1992), 苧阪・ 苧阪（1994），および苧阪（1998）に準じた。文を読 む速度はテスト全体を通して一定になるように教示さ れた。実験の途中で速度が変化しているように判断さ れた場合には注意が与えられた。

いずれの RSTも2 文条件から5文条件までそれぞ れ3 試行がおこなわれた。 4 種類の RST の試行順序 は被験者ごとにカウンターバランスされた。 RST ス パンの評定方法は，各文条件 3 試行のうち 2 試行正解 の場合はそのセットをパスしたものとし，1試行だけ 正解のときは 0.5 点の評価点を加えた。

\section{結果}

\section{RST 得点}

RST の成績にはスパン（SPN）と，正答した試行 に打ける再生単語の総数（word-totally-recalled,
WTR）の 2 種類の評価值が用いられた. SPNと WTRの得点をHSS と LS の被験者群ごとに Figure 1 に示す。

RSTの 2 種類の評価值ごとに，フォーカス（F， $\mathrm{NF}$ ，被験者群（HSS, LSS）打よび文の長さ（L, S) の3 要因で分散分析を扔こなった。その結果，フォー カスの主効果が二つの評価值で認められた（SPN, $F(1,38)=18.52, p<.0001$; WTR, $F(1,38)=17.45$, $p<.0001)$. さらに, 被験者群の主効果も二つの評価 值で有意となった（SPN， $F(1,38)=49.77, p<.0001$; WTR, $F(1,38)=51.21, p<.0001)$. 被験者群とフォ 一カスの交互作用は有意ではなかったが，SPNにつ いては傾向が認められた $(F(1,38)=3.33, p<$ 0.076). しかし, 文の長さの効果については, 主効果 および交互作用ともに認められなかった。

被験者群とフォーカスの交互作用に傾向が認められ たので，試みに被験者群とフォーカスの交互作用につ いての単純主効果の検定を抢こなった。その結果, LSS については二つの評価値でフォーカスの単純主 効果が認められた $(\mathrm{SPN}, F(1,38)=15.63, p<.001$;
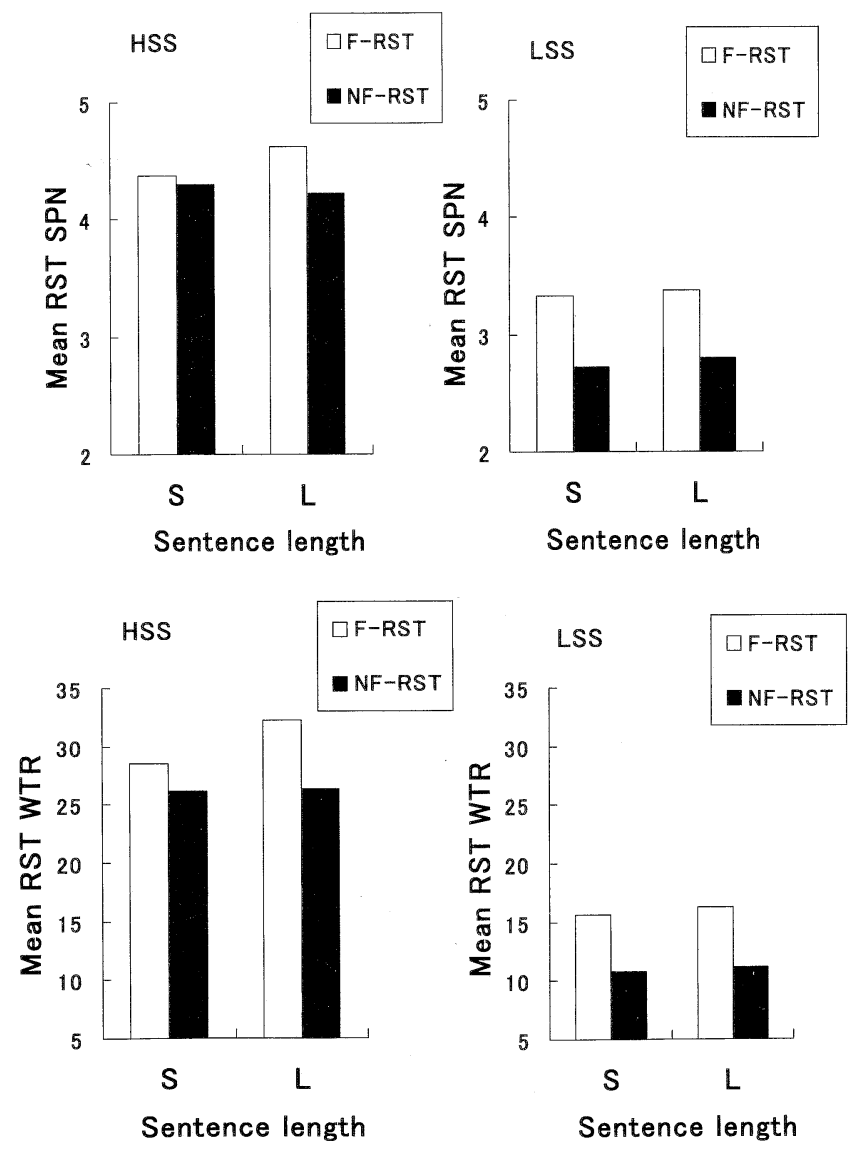

Figure 1. Mean SPN (upper) and WTR (lower) for F-RST and NF-RST in HSS and LSS subject groups. 
WTR, $F(1,38)=16.11, p<.001)$. しかし, HSS では WTR $(F(1,38)=5.48, p<.05)$ については $5 \%$ 水準 で単純主効果が認められたが, SPN については有意 な単純主効果は認められなかった $(F(1,38)=2.84$, $p<.10)$.

\section{侵入エラー}

被験者が RST の単語再生で報告したエラーを，各 RST 間で比較した。特に同じ文内で出現したターゲ ット語以外の単語を報告したエラー（侵入エラー）の 総数をもとめた。被験者群ごとの侵入エラー総数の平 均值を Figure 2 に示す.

侵入エラー数をフォーカス，被験者群および文の長 さの 3 要因分散分析した結果, フォーカスの主効果 $(F(1,38)=48.15, p<.0001)$ と被験者群の主効果 $(F(1,38)=8.25, p<.01)$ が認められた。さらに, フ オ一カスと被験者との交互作用も有意であった $(F(1,38)=5.79, p<.05)$. しかし, 文の長さの効果
は主効果および交互作用ともに認められなかった。

交互作用が認められたので, 被験者群ごとにフォー カスの単純主効果の検定をおこなった。その結果, HSS およびLSSともにフォーカスの単純主効果が認 められた（HSS, $F(1,38)=19.35, p<.0001 ; \mathrm{LSS}$, $F(1,38)=48.76, p<.0001)$.

\section{フォーカス語の侵入エラー}

非フォーカス条件での侵入エラーには，フォーカス 語を誤って報告するエラーが多く出現した。そこで， 非フォーカス条件での侵入エラーについて，フォーカ ス語を誤って再生しているエラー (focus-intrusion, FI）とそれ以外のエラー (non-focus-intrusion, NFI) に分類した。Figure 3 に被験者群ごとのFI と NFI の平均值を示すＦI と NFI を 1 要因として，エラー の種類, 文の長さおよび被験者群について 3 要因分散 分析を扔こなった。 その結果，エラーの種類の主効果 が認められた $(F(1,38)=7.15, p<.001)$.また，被
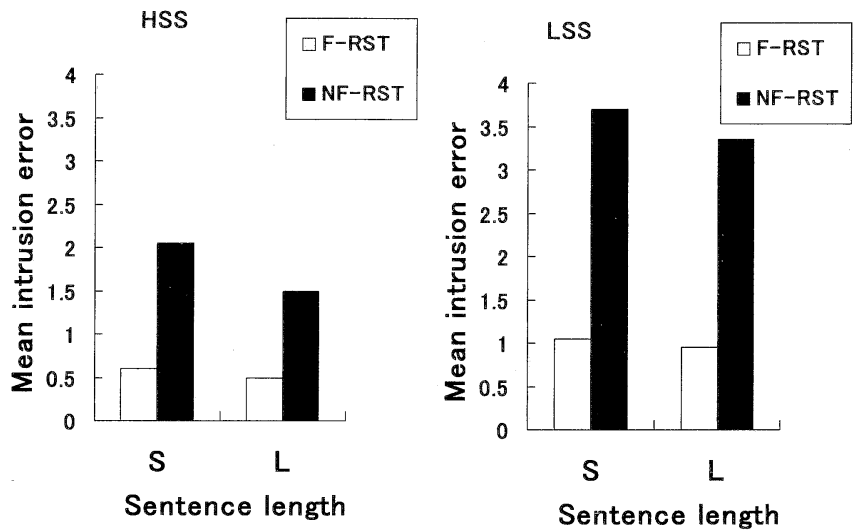

Figure 2. Mean intrusion errors for F-RST and NF-RST in HSS and LSS subject groups.
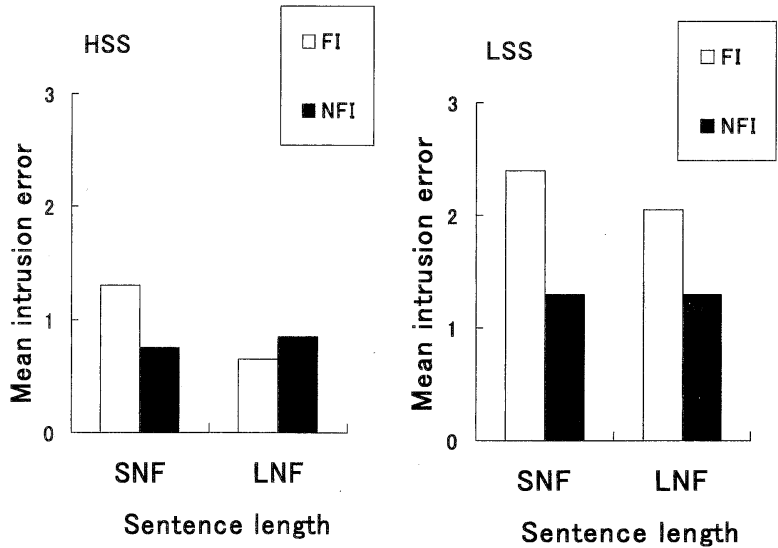

Figure 3. Mean FI and NFI intrusion errors in HSS and LSS subject groups. 
験者群の主効果 $(F(1,38)=7.89, p<.001)$ も認めら れた。一方, 文の長さの効果は認められなかった。工 ラーの種類と被験者の交互作用は有意ではなかったが 傾向が認められた $(F(1,38)=3.33, p<0.076)$. 交互 作用に傾向が認められたので，被験者群ごとにエラー の種類についての単純主効果の検定を抢こなった。そ の結果, HSS ではエラーの種類による差が認められ なかったが, LSS では，エラーの種類に差が認めら れた $(F(1,38)=11.83, p<.01)$.

\section{考察}

\section{RST 得点}

RST 得点の結果から，F-RST ではNF-RSTよりも SPN とWTRがともに高くなることが確認された。 文中のフォーカス語が記憶するべきターゲット語と一 致する場合には，文の意味的な理解と統合を扔こなう 処理過程が保持とうまく適合するため, 保持を促進す るものと考えられる。しかし，ターゲット語がフォー カス語と一致しない場合には, 文理解からの促進はな く, 被験者は文の統合処理が完了する文末まで，フォ 一カス語を保持するとともにターグット語を保持しな ければならない。これには，ワーキングメモリ資源を より多く必要とするものと考えられる。加えて, ター ゲット語はフォーカス語と干渉するものと推定され る、被験者は, ターゲット語の保持に努めるのである が，文の読みに容量をとられるため，ターゲット語の 保持が不安定なものとなったと考えられる。

一方, 文の長さの効果は認められず, さらにフォー カスとの干渉も認められなかった. Towse et al. (1998) は Cowan, Day, Saults, Keller, Johnson, \& Flores（1992）の記憶実験パラダイムを文の提示に応 用して, 最初の文を長くした条件と最後の文を長くし た条件でRST 得点の比較を抢こなっている. 最後の 文を長くした場合は最初の文を長くした場合よりも， 最初の文の文末単語の保持時間が長くなると予測され た。結果は予測したように，最後の文を長くした場合 にRST成績が低下した。彼らはこの結果から，被験 者がRST 遂行に課題転換をしている可能性を示唆し たのである。この仮説に従うならば，本実験でも文の 長さが長くなると，それだけターゲットの保持時間が 延長するため成績が低下寸ると予測される。しかし, RST 得点は文の長さでは変化せず，フォーカスの効 果のみが認められたのである。もし読みと保持を課題 転換しているならば, ターゲット語がフォーカス語で あるか否かは，文の読みには影響をおよばさないであ ろうから，フォーカス文と非フォーカス文で成績は変 化しないと考えられる。しかし，フォーカスの効果が 認められ, 結果は仮説を支持するものではなかった。 したがって, 本実験結果から, 被験者がRST遂行に
際して必ずしも課題転換を抢こなっていると考えるこ とは難しいであろう。

また, フォーカスの効果は HSSよりも LSSでより 大きい傾向が認められた。この結果は, LSSがフォ 一カスの影響を強く受けることを示唆している.ター ゲット語がフォーカス語と異なると, 文理解による夕 ーゲット語保持への促進効果が得られず，そのためよ り多くのワーキングメモリ資源を必要とする。この傾 向は, 容量に余裕のない LSS に強く, 成績の低下を 招いたのであろう。一方，HSS では RST スパン得点 にフォーカスの効果が認められず，WTR 指標でもフ オーカスの効果はLSS ほどには顕著ではなかった。 これは, ターゲット語がフォーカス語と異なる場合で も，HSS は資源に余裕があるため課題遂行にさほど 影響しなかったものと考えられる。

以上の結果は, RST 遂行には読みと単語の保持が 交互にはたらくのではなく，文の理解が単語の保持を 促進したり干渉したりというように，相互に影響しあ うことを示唆するものである。

\section{侵入エラー}

侵入エラーは, F-RST に比較してNF-RST で増加 することが確かめられた。これは，NF-RSTではフ オーカスによるターゲット語の保持への促進がなく, 課題が一層資源消費につながり，そのため抑制機能が うまく作用しなかったものと推察される。

抑制機能に関して Gernsbacher（1993）は，文章理 解における重要性を指摘し, 文章理解の成績の高い被 験者と低い被験者を比較したところ, 後者は前者より も文章理解に関連しない情報の抑制ができないことを 報告している（Gernsbacher \& Faust, 1991)。本実験 に扔けるNF-RST での侵入エラーの増加結果を, 同 様の抑制機能の低下で説明をすることは可能であろ う。しかし，NF-RST で抑制できないのは，Gernsbacher（1990）の指摘するような文章理解に関連しない 情報ではない。NF-RSTでの侵入エラーには, フォ 一カス語が多いことが確かめられており, NF-RST で抑制できなかった内容はフォーカス語すなわち文の 理解に重要な情報だったのである。

また, 侵入エラーはHSSよりも LSS で多数出現し た。さらに，フォーカス語を誤って報告しているエラ 一はLSSに顕著であった。この結果は, LSS がフォ 一カス語の抑制に特に困難を示していることを裏付け ている.

De Beni et al.（1998）は，RST 課題に扔いて侵入工 ラーを測定して, 文章理解に劣る被験者は侵入エラー が多いことを指摘している。さらに，文ではなく単語 を継時的に提示して, RST と同様に最後の単語の保 持を求めている。その際に, ある特定の単語（動物の 単語）に対して反応を要求することにより注意を向け 
させた場合, 注意を向けた動物単語の侵入エラーが多 くなることを指摘している。この結果は, NF-RST でのフォーカス語の侵入エラーに類似するものであ る。しかし, De Beni et al.（1998）の結果に扔いて被 験者が注意を向けた対象は，外的な手がかりに導かれ たものであった。それに対して，NF-RSTで被験者 が注意を向けた対象，すなわちフォーカ久語は，外的 な手がかりにより形成されるものではなく, 被験者が 内的に形成したものである点は留意すべきであろう。 LSS は注意を向けた対象の抑制ができないだけでは なく，内的に形成したフォーカスを抑制してターゲッ 卜語の保持に注意を向ける，つまりフォーカスを更新 することに困難を生じているのである。

\section{ワーキングメモリにおけるフォーカスの重要性}

本研究では，RSTに扔けるフォーカスの効果が認 められた。また, フォーカスの効果は, 容量に余裕の ある HSSよりも容量に余裕のない LSS でより強く影 響する傾向がみられた。侵入エラーにもフォーカスの 効果が認められた。そのエラーの多くはフォーカス語 の愦再生であり，特にLSS で認められた。このこと から，RSTでの測定内容が抑制機構と関連している ことは十分考えられるが，抑制機構のみでRST の測 定内容を説明できるとは言いがたい. 事実, LSS で も，F-RSTではNF-RST に比べて成績がよかったの である。もし，抑制機構のみに問題があるとすれば, 彼らはF-RSTでも低得点しか得られなかったはずで ある。

そこで，RST の成績に影響を及ほす要因は抑制機 構以外にもあると考元られる。その要因として，フォ 一カスの形成とフォーカスの更新が挙げられる。フォ 一カスは読み手が内的に形成するものであるが，その 形成過程には，長期記憶からの情報の検索（Ericsson \& Kintsch, 1995), 構文, 統語や意味的情報の理解抒 よびその活用（Just \& Carpenter, 1992）といったワー キングメモリでの制御が必要である。一方，フォーカ スの更新には，一度形成したフォーカスを変更するた め柔軟に対処できる注意の転換システムが要請され る. RSTの遂行には，ワーキングメモリのなかでも とくに中央実行系 (central executive) の関与が指摘 されている (Baddeley, 1992; Just \& Carpenter, 1992). したがって，フォーカスの形成と更新は主として中央 実行系がその役割を担っているものと考えられる。た だし，フォーカスの形成とフォーカスの更新のどちら が HSS と LSS の差を大きくしているかについては， ここで結論することは難しく, 今後の課題である.

このように，RST の遂行にはフォーカスを中心と する文理解が基礎となることが確認された。また，処 理機能と保持機能はワーキングメモリ資源を競合する だけでなく, 相互に促進して文理解のための統合シス
テムに寄与することがわかった。フォーカスは文理解 の基礎でありその過程を駆動するものである。そこ で，フォーカ久はワーキングメモリに扔いて重要であ ると考えられる.

最後に，文の読みにおいてはたえず内的にフォーカ スを作り上げていくことが要求されているものと考え られる。つまり，読みに扔ける理解とは内的フォーカ スを不断に探索しかつ更新する作業であるといえる. したがって, フォーカスが生起する可能性に対して, 文脈の形成, 時間的統合において柔軟に対処すること がワーキングメモリの重要な役割であると考えられ る。

\section{引用文献}

Baddeley, A. D. 1986 Working memory. New York: Oxford University Press.

Baddeley, A. D. 1992 Working memory. Science, 255, 556-559.

Baddeley, A. D., Logie, R., Nimmo-Smith, I., \& Brereton, R. 1985 Components of fluent reading. Journal of Memory and Language, 24, 119-131.

Bolinger, D. 1986 Intonation and its parts. Palo Alto, CA: Stanford University Press.

Carpenter, P. A., \& Just, M. A. 1989 The role of working memory in language comprehension. In D. Klar \& K. Kotovsky (Eds.), Complex information processing: The impact of Herbert A. Simon. Hillsdale, NJ: Lawrence Erlbaum. Pp. 31-68.

Case, R., Kurland. M., \& Goldberg, J. 1982 Operational efficiency and growth of short term memory span. Journal of Experimental Child Psychology, 33, 386-404.

Conway, A. R. A., \& Engle, R. W. 1994 Working memory and retrieval: A resource-dependent inhibition model. Journal of Experimental Psychology: General, 123, 354-373.

Cowan, N., Day, L., Saults, J. S., Keller, T. A., Johnson, T., \& Flores, L. 1992 The role of verbal output time in the effects of word length on immediate memory. Journal of Memory and Language, 31, $1-17$.

Daneman, M., \& Carpenter, P. A. 1980 Individual differences in working memory and reading. Journal of Verbal Learning and Verbal Behavior, 19, 450466.

Daneman, M., \& Carpenter, P. A. 1983 Individual differences in integrating information between and within sentences. Journal of Experimental Psychology: Learning, Memory and Cognition, 9, 561-583.

De Beni, R., Palladino, P., Pazzaglia, F., \& Cornoldi, C. 1998 Increases in intrusion errors and working memory deficit of poor comprehenders. Quarterly Journal of Experimental Psychology, 51A, 305-320. 
Engle, R. W., Conway, A. R. A., Tuholski, S. W., \& Shisler, R. J. 1995 A resource account of inhibition. Psychological Science, 6, 122-125.

Ericsson, K. A., \& Kintsch, W. 1995 Long-term working memory. Psychological Review, 102, 211245.

Gernsbacher, M. A. 1993 Less skilled readers have less efficient suppression mechanisms. Psychological Science, 4, 294-298.

Gernsbacher, M. A., \& Faust, M. E. 1991 The mechanism of suppression: A component of general comprehension skill. Journal of Experimental Psychology: Learning, Memory, and Cognition, 17, 245262.

Just, M. A., \& Carpenter, P. A. 1992 A capacity theory of comprehension: Individual differences in working memory. Psychological Review, 99, 122-149. 近藤洋史・森下正修・苧阪直行 1999 読みのワーキ ングメモリとリーディングスパンテスト 心理学評 論, 42, 506-523.

(Kondo, H., Morishita, M., \& Osaka, N. 1999 Working memory in reading and reading span test. Japanese Psychological Review, 42, 506-523.)

久野 暲 1978 談話の文法 東京：大修館書店 (Kuno, S. 1978 Discourse and grammer. Tokyo: Taishukan-Shoten.)

La Pointe, L. B., \& Engle, R. W. 1990 Simple and complex word spans as measures of working memory capacity. Journal of Experimental Psychology: Learning, Memory and Cognition, 16, 1118-1133.

Masson, M. E., \& Miller, J. A. 1983 Working memory and individual differences in comprehension and memory of text. Journal of Educational Psychology, 75, 314-318.

May, C. P., Hasher, L., \& Kane, M. J. 1999 The role of interference in memory span. Memory and Cognition, 27, 759-767.

苧阪満里子 1998 読みとワーキングメモリ 艼阪直 行 (編) 読み——脳と心の情報処理——朝倉書 店 Pp. 239-262.

(Osaka, M. 1998 Reading and working memory. In N. Osaka (Ed.), Reading: Information processing of brain and mind. Tokyo: Asakura-Shoten. Pp. 239-262.)

苧阪満里子 2000 ワーキングメモリと言語理解の脳 内機構 苧阪直行（編）脳とワーキングメモリ 京都大学学術出版会 Pp. 157-180.

(Osaka, M. 2000 Brain mechanism of working memory and language comprehension. In N. Osaka (Ed.), Brain and working memory. Kyoto: Kyoto University Press. Pp. 157-180.)

Osaka, M., \& Osaka, N. 1992 Language-independent working memory as measured by Japanese and English reading span tests. Bulletin of the Psychonomic Society, 30, 287-289.

苧阪満里子・苧阪直行 1994 読みとワーキングメモ リ容量——日本語版リーディングスパンテストによ る測定— 心理学研究, 65, 339-345.

(Osaka, M., \& Osaka, N. 1994 Working memory capacity related to reading: Measurement with the Japanese version of reading span test. Japanese Journal of Psychology, 65, 339-345.)

Perfetti, C. A., \& Goldman, S. R. 1976 Discource memory and reading comprehension skill. Journal of Verbal Learning and Verbal Behavior, 15, 3342.

Shah, P., \& Miyake, A. 1996 The separability of working memory resources for spatial thinking and language processing: An individual differences approach. Journal of Experimental Psychology: General, 125, 4-27.

Towse, J. N., Hitch, G. J., \& Hutton, U. 1998 A reevaluation of working memory capacity on children. Journal of Memory and Language, 39, 195217.

Towse, J. N., Hitch, G. J., \& Hutton, U. 2000 On the interpretation of working memory span in adults. Memory and Cognition, 28, 341-348.

Turner, M. L., \& Engle, R.W. 1989 Is working memory capacity task dependent? Journal of Memory and Language, 28, 127-154.

- 2000.5.11 受稿, 2001.3.3 受理—— 